\title{
« La Forteresse de Dimdim ou l'épopée héroïque de Khan-Au-Bras-d'or ». The Journal of Kurdish Studies, V, 2005, pp. 1-18, introduction par Joyce Blau.
}

\section{Christine Allison}

\section{(2) OpenEdition}

Journals

Édition électronique

URL : http://journals.openedition.org/abstractairanica/21341

DOI : 10.4000/abstractairanica.21341

ISSN : 1961-960X

Éditeur :

CNRS (UMR 7528 Mondes iraniens et indiens), Éditions de l'IFRI

Édition imprimée

Date de publication : 15 mai 2007

ISSN : 0240-8910

Référence électronique

Christine Allison, « "La Forteresse de Dimdim ou l'épopée héroïque de Khan-Au-Bras-d'or ». The

Journal of Kurdish Studies, V, 2005, pp. 1-18, introduction par Joyce Blau. », Abstracta Iranica [En ligne], Volume 28 | 2007, document 390, mis en ligne le 18 septembre 2007, consulté le 25 septembre 2020 URL : http://journals.openedition.org/abstractairanica/21341 ; DOI : https://doi.org/10.4000/ abstractairanica. 21341

Ce document a été généré automatiquement le 25 septembre 2020.

Tous droits réservés 
« La Forteresse de Dimdim ou l'épopée héroïque de Khan-Au-Brasd'or ». The Journal of Kurdish Studies, V, 2005, pp. 1-18, introduction par Joyce Blau.

\author{
Christine Allison
}

1 As the introduction explains, this article reproduces a lecture given by Thomas Bois at SOAS in 1972, and which remained unpublished at his death in 1975. Unusually for a Kurdish historical event commemorated in oral literature, the taking of castle Dimdim and the massacre of its inhabitants by Šāh 'Abbās in 1609CE is also recounted in a written source, by Iskandar Beg Munšī, who witnessed the events concerned. Bois makes a very thorough comparison of various folkloric versions of the tale with the historical source and observes how heroic and fantastic elements are added to the historical nucleus. However, he treats them as if they were manuscript sources attesting some kind of Urform, not fully taking into account the implications of their existence as oikotypes; moreover he seems unaware that the name 'Prince Goldenhand' is older than this epic, being associated in the Šaraf-nāme (1596CE) with another hero who won back his castle from enemy occupation. Nevertheless, this article, both concise and rich, is an essential source of information on one of the most important traditions in Kurdish folklore. 
INDEX

Thèmes : 11.4. Littérature kurde

\section{AUTEURS}

CHRISTINE ALLISON

INaLCO / Mondes iranien et indien - Paris 